\section{As cidades invisíveis: a favela como desafio para urbanização mundial}

\author{
Ricardo Ojima*
}

\begin{abstract}
UNFPA. State of world population 2007: unleashing the potential of urban growth. New York: UNFPA, 2007.
\end{abstract}

DAVIS, M. Planeta favela. Tradução Beatriz Medina. São Paulo: Boitempo, 2006.

O recente lançamento do Relatório sobre a Situação da População Mundial 2007, do Fundo de População das Nações Unidas (UNFPA, 2007), resgatou o debate sobre o processo de urbanização no Brasil e no mundo, agora sob a luz de novas preocupações e desafios globais. Não por acaso, a discussão concentra-se em torno dos países em desenvolvimento, afinal, segundo estimativas da Organização das Nações Unidas (ONU), vivemos um momento único na história da humanidade: pela primeira vez teremos mais da metade da população mundial residindo em áreas classificadas como urbanas. Segundo as mesmas estimativas, em 2030, teremos um adicional de cinco bilhões de pessoas vivendo em cidades.

Se, por um lado, receia-se que essa situação agrave os desafios já enfrentados pelos países em desenvolvimento, por outro, como sugere o subtítulo do Relatório da ONU, este seria um momento simbólico para refletir sobre os potenciais positivos que o crescimento urbano pode trazer. Ou seja, não se trata de imaginar um cenário caótico de megacidades inchadas pelo crescimento da população e da pobreza urbana, mas sim de avaliar, de maneira isenta, as condições existentes para propor, sobretudo aos países que passarão pela transição urbana nos próximos anos, os caminhos alternativos que possam conduzir à redução da pobreza e da desigualdade social.

Embora os contextos sociais, históricos e econômicos sejam distintos, a experiência latino-americana pode ser um ponto de apoio importante para os países que hoje procuram meios para enfrentar os dilemas do crescimento urbano, evitando suas conseqüências perversas e de modo que realmente se consolide um momento especial para o desenvolvimento humano.

Um dos aspectos que assumem maior evidência e receio é a pobreza urbana e sua expressão física nas grandes cidades: as favelas. Consideradas a expressão das mazelas do crescimento urbano não planejado e do aumento da pobreza urbana, as favelas aglutinam a população mais exposta a condições e situações de extrema vulnerabilidade social e ambiental, sobretudo quando o debate em torno das mudanças climáticas confirma o que já era esperado: a população pobre será a mais fortemente afetada pelas alterações no clima projetadas para um futuro não muito distante. Portanto, se a transição urbana é um processo de mão única, será nas favelas e nos países em desenvolvimento que os processos tornarse-ão mais complexos.

Em seu livro, Planeta favela, Mike Davis (2006) evidencia sua preocupação em relação à generalização das favelas. De modo geral, o autor se vale de um conjunto expressivo de dados e informações sobre os mais diversos países para provar sua idéia central: a "favelização" do mundo. Tendo como ponto de partida o relatório da UN-Habitat de 2003, que aborda os desafios das favelas no mundo, Davis procura mostrar que, a despeito das diversas formas e expressões que podem ter, as favelas constituem o

\footnotetext{
* Sociólogo e doutor em Demografia. Pesquisador colaborador do Núcleo de Estudos de População (Nepo/Unicamp) e do Departamento de Demografia (DD/IFCH/Unicamp). Bolsista de pós-doutorado da Fundação de Amparo à Pesquisa do Estado de São Pauo - Fapesp.
} 
principal pólo de concentração da pobreza, sobretudo nos países que passam por um processo de urbanização mais acelerado.

O autor destaca, ainda, a existência de uma exploração imobiliária nos moldes mais perversos dentro das favelas, pois, ligeiramente diferente da realidade brasileira, as principais favelas africanas, por exemplo, organizam-se em torno de alguns poucos proprietários que colocam à "disposição" desta parcela empobrecida da população barracos sem nenhuma infra-estrutura. Para se ter uma idéia da dimensão dessa exploração, na favela de Kibera, em Nairóbi (Quênia), onde se aglomeram mais de 800 mil pessoas, sem água potável, sem esgoto e sem instalações sanitárias, os "locatários" tornam-se escravos das favelas, sobrevivendo com renda mensal de menos de 30 dólares.

Embora as diferenças regionais sejam importantes e, em certa medida, contenham nas denominações locais (favela, slums, pueblos jovenes ou katchi obadi) as raízes dos processos sociais que as configuram, a verdade é que essa parcela da população torna-se mais expressiva diante da transição urbana prevista para os próximos anos. Dessa forma, é importante que esteja claro sobre o que se está falando ao usar o termo favela.

Para isso, é necessário avançar em abordagens metodológicas que permitam analisar as realidades em termos comparativos, caso contrário, dizer que o mundo está se tornando uma grande favela pode ser uma generalização muito pouco significativa. Segundo o State of the world's cities 2006/7, publicado pela UN-Habitat (2006), as taxas de crescimento da população em favelas são equivalentes àquelas para a população urbana. Porém, sua concepção de favela é muito pragmática, como quase todas as estimativas globais podem ser, pois considera cinco dimensões ${ }^{1}$ para classificar uma habitação como favela.

Neste sentido, mesmo que exista recomendação para adaptar os critérios segundo particularidades regionais, não é possível incluir dimensões sociais importantes, como acesso a saúde e educação, bem como aspectos culturais e padrão de consumo dessa população.

Embora o caso brasileiro ainda seja preocupante, a África, de maneira geral, encontra-se em situação muito mais grave, diante da total ausência de políticas sociais que busquem minimizar as vulnerabilidades sociais e da exploração imobiliária dentro das favelas. Segundo o relatório da UN-Habitat (2006, p.40), em um quadro comparativo global, o Brasil está em fase de estabilização das taxas de crescimento das favelas, enquanto a maior parte da África Sub-Sahariana encontra-se em situação gravíssima, devido às já elevadas proporções de população em favelas, somadas às altas taxas de crescimento.

Humanidade excedente? É a pergunta colocada por Davis (2006) para pensar os processos que se configuram nos limites dessa favelização do mundo. A informalidade do mundo econômico cresce lado a lado com a população favelada e, mesmo que não sejam totalmente coincidentes, se sobrepõem de modo integrado. Enfim, aumenta o número de pessoas invisíveis em cidades invisíveis. Invisíveis aos olhos do Estado e alheios ao mercado formal, tornam-se figurantes em um filme em que os protagonistas não querem ser reconhecidos.

\footnotetext{
1 Segundo definido por um grupo de trabalho em novembro de 2002 pela UN-Habitat, para ser considerada habitação em favela, o domicílio deve se enquadrar em pelo menos uma das seguintes privações: 1) durabilidade da habitação; 2) densidade domiciliar máxima de três pessoas por cômodo; 3) acesso suficiente a água potável; 4) acesso a instalações sanitárias; e 5) posse legal da terra ou alguma forma de proteção legal.
} 


\section{Referências bibliográficas}

UN-HABITAT. State of the world's cities 2006/7. London, Earthscan, 2006.
The challenge of slums: global report on human settlements 2003. London, Earthscan, 2003.

Recebido para publicação em 31/07/2007. Aceito para publicação em 12/11/2007. 